\title{
Use of Antimicrobial Treatments and Modified Atmosphere to Extend the Shelf Life of Fresh Sausages
}

\author{
Gammariello D, Incoronato AL, Conte A and DelNobile MA* \\ Department of Agricultural Sciences, The Food and Environment, University of Foggia, Via Napoli, 25-71122 Foggia, Italy
}

\begin{abstract}
The application of technologies, dipping treatments and packaging under modified atmosphere conditions, to prolong the shelf life of fresh pork sausages were assessed. The work was divided into two subsequent experimental trials. The first trial was aimed to select the concentration of essential oils. For this purpose, bay with nutmeg oils and fennel with black pepper oils were properly combined to dip of meat according to Two Central Composite Designs (CCD). The second trial was aimed to combine the meat dipping with the optimal concentrations of oils and sodium lactate solution $(60 \%)$. All samples were packaged under modified atmosphere (MAP: $30 \% \mathrm{CO}_{2} 70 \% \mathrm{~N} 2$ ). Total Aerobic Bacteria and sensory quality were monitored during the refrigerated storage and the shelf life was calculated as the lowest value between microbiological acceptability limit (MAL) and sensory acceptability limit (SAL). Results of two steps showed that an increase of sausage shelf life could be obtained combining more technologies. In particular, the shelf life of about 18 days was obtained combining the dipping of meat first in sodium lactate solution then in optimal concentrations of essential oils ( $1.25 \%$ fennel and $2.5 \%$ black pepper; $2.5 \%$ bay and $1.25 \%$ nutmeg), compared to the untreated samples that recorded a shelf life of two days.
\end{abstract}

Practical application: The shelf life extension of fresh meat products like sausages that generally have a short shelf life, represents a challenge for food companies. Short shelf life causes problems to food distribution, increases the food loss with relevant impact also on the environment. Therefore, the use of technological options to be used during processing and packaging could have important economic feedback.

Keywords: Fresh meat sausage; Sodium lactate; Essential oils; MAP; Shelf life

\section{Introduction}

Fresh sausage is a perishable food and requires protection from spoilage during its preparation, storage and distribution to give it the desired shelf life. One approach to extend the shelf life of fresh meat is to introduce antimicrobials, preferably natural compounds [1-6]. Because the microbial contamination of meat products occurs primarily at the surface due to post-processing handling, dipping treatments with antimicrobial preservatives could be promising, thus helping to prevent the growth of spoilage microorganism $[7,8]$.

Essential oils (EO) are well-known inhibitors of microorganisms [9] and numerous workers reported their antimicrobial activities [10, 11]. Fennel (Foeniculum vulgare), with a sweet, earthy flavour, which belongs to the family Apiaceae has long been used as herbal remedy. Medicinally, fennel is used as analgesic, antioxidant, antispasmodic, anti-inflammatory, carminative and diuretic [12-15]. Black peppercorn (Piper nigrum) is a commonly used spice. The essential oil of black peppercorn has been shown to possess antimicrobial activity [16]. Bay (Laurus nobilis) is an evergreen tree native to the Mediterranean region. Laurel leaves have been used as flavouring ingredients and they have been traditionally added to meat, fish and poultry meals $[17,18]$. Several studies have screened the potential capacity of laurel essential oil as antimicrobial agent [9] and antioxidant compounds [17]. Nutmeg (Myristica fragans) is a widely used spice and flavouring ingredient in food products, with possible health beneficial effects, such as anti-inflammatory activity [21-23]. Sodium salts of organic acids, such as lactic, acetic and citric, have been used to control microbial growth, improve sensory attributes and extend the shelf life of various food systems [24] including meat [25- 28], poultry [29], and fish [3032]. Furthermore, these salts are widely available at low costs [33]. Sodium lactate, produced by microbial fermentation, is the sodium salt of natural lactic acid and is a normal component of muscle tissue. Since
1989, the potential benefits of sodium lactate as antimicrobial agent spurred interest in research of meat products [26]

MAP is also considered as an effective method for food preservation. It is well known as a method for extending the shelf life of a variety of foods, including fresh meat and poultry [39-41]. The application of MAP has grown greatly in recent years, but optimization of gas composition is still critical to ensure both quality and safety of food [42]. The application of carbon dioxide to inhibit bacterial growth and nitrogen to avoid oxidation of fats in poultry meat packages can generate good preservation effects [42].

Although numerous studies have been done to evaluate the antimicrobial activity of the above-mentioned oils, there are only few studies on the combination of essential oils and sodium lactate in meat products [44]. Therefore, the present study was undertaken to investigate the effect of essential oils, sodium lactate and MAP for the improvement of fresh sausage shelf life during storage at $4^{\circ} \mathrm{C}$. To the aim, the study was organized into two experimental trials: in the first one, the essential oils (i.e. bay with nutmeg and fennel with black pepper) were combined and two Central Composite Designs were performed. In the second trial, the best concentrations of essential oils were used in combination with dipping in sodium lactate and packaging under MAP.

*Corresonding author: Del Nobile MA, Department of Agricultural Sciences, the Food and Environment, University of Foggia, Via Napoli, Foggia, Italy, Tel: (+39) 881589 242; E-mail: matteo.delnobile@unifg.it

Received April 01, 2015; Accepted May 01, 2015; Published May 08, 2015

Citation: Gammariello D, Incoronato AL, Conte A, DelNobile NA (2015) Use of Antimicrobial Treatments and Modified Atmosphere to Extend the Shelf Life of Fresh Sausages. J Food Process Technol 6: 456. doi:10.4172/2157-7110.1000456

Copyright: @ 2015 Gammariello D, et al. This is an open-access article distributed under the terms of the Creative Commons Attribution License, which permits unrestricted use, distribution, and reproduction in any medium, provided the original author and source are credited. 


\section{Materials and Methods}

\section{Sausages production}

Pork meat was kindly provided by a meat processing company, Dodaro (Dodaro spa, Spezzano Albanese, Cs, Italy). The composition of sausages, given by the company above-mentioned, was: minced meat $(60 \%)$, animal fat $(20 \%)$, salt $(1.5 \%)$, dextrose $(0.5 \%)$, spices $(10.8 \%)$, sodium salt of ascorbic acid, E301 (0.2\%). The minced meat was mixed with all ingredients in a mixer to obtain sausage batter. The batter was then stuffed into natural casings of diameter $2.5 \mathrm{~cm}$, using a mechanical bagging and the stuffed sausages were linked.

\section{Trial 1}

During the first trial, the concentration of essential oils varied according to a two-factor, three-level Central Composite Design (CCD) [45] and two experimental plains were performed to combine fennel oil with black pepper oil and bay oil with nutmeg oil. The coded levels and the combinations of the experimental design are reported in Table $1(\mathrm{a}, \mathrm{b}) .10 \mathrm{Kg}$ batch of raw meat, for each CCD, was divided into $1 \mathrm{~kg}$ parts to which the appropriate antimicrobial treatment was added. For each run (see table $1 \mathrm{~b}$ ), the meat pieces were dipped into $100 \mathrm{~g}$ extra virgin olive oil solution (EVO) enriched of essential oils (EO) and after dipping they were ground. . After $10 \mathrm{~min}$ of dipping, meat pieces were ground by a mincing machine (Everest, Sberlati \& C. s.n.c., Rimini, Italy) equipped with an $8 \mathrm{~mm}$ grinding plate. The solution left from dipping were added to the obtained minced meat and mixed with the ingredients above mentioned. Twenty sausages of $50 \mathrm{~g}$ for each run were obtained. Each combination was repeated twice, and untreated sausages were used as the control. The sausages were packed in air and stored at $4^{\circ} \mathrm{C}$ for 8 days. The bags were $220^{*} 320 \mathrm{~mm}$ long, and they are constituted by an anti-fog high-barrier multilayer film, made up of polyethylene terephthalate, ethylene-vinyl alcohol and polyethylene, with oxygen transmission rate of $2.64 \pm 0.12 \mathrm{cc} / \mathrm{m} 2$ day, carbon dioxide transmission rate of $2.5 \pm 0 \mathrm{cc} / \mathrm{m} 2$ day at $23^{\circ} \mathrm{C}$ and $0 \% \mathrm{RH}$ and water vapour transmission rate (WVTR) of $0.69 \pm 0.01 \mathrm{~g} / \mathrm{m}^{2}$ day at $23^{\circ} \mathrm{C}$ and $90 \% \mathrm{RH}$, thickness of $90 \mu \mathrm{m}$, kindly provided by Di Mauro (Officine Grafiche spa, Salerno, Italy).

\begin{tabular}{|c|c|c|c|c|}
\hline \multirow{2}{*}{ run } & \multicolumn{2}{|c|}{ Experimental factors } & \multicolumn{2}{c|}{ Concentration (\%) } \\
\cline { 4 - 5 } & \multicolumn{2}{|c|}{} & fennel or bay & $\begin{array}{c}\text { black pepper or } \\
\text { nutmeg }\end{array}$ \\
\hline Cnt & -1 & -1 & 0 & 0 \\
\hline 2 & -1 & 1 & 0 & 0.25 \\
\hline 3 & 1 & -1 & 2.5 & 0 \\
\hline 4 & 1 & 1 & 2.5 & 2.5 \\
\hline 5 & -1 & 0 & 0 & 1.25 \\
\hline 6 & 1 & 0 & 2.5 & 1.25 \\
\hline 7 & 0 & -1 & 1.25 & 0 \\
\hline 8 & 0 & 1 & 1.25 & 2.5 \\
\hline 9 & 0 & 0 & 1.25 & 1.25 \\
\hline 10 & 0 & 0 & 1.25 & 1.25 \\
\hline
\end{tabular}

Table 1a: Run, experimental factors and concentrations of Central Composite Design (CCD).

\begin{tabular}{|c|c|c|}
\hline Level & fennel or bay & black pepper or nutmeg \\
\hline-1 & 0 & 0 \\
\hline 0 & 1.25 & 1.25 \\
\hline 1 & 2.5 & 2.5 \\
\hline
\end{tabular}

Table 1b: Coded values of experimental factors.

\section{Trial 2}

The second trial focused on the combined effects of dipping in two solution, sodium lactate $60 \%(\mathrm{NaL})$ and EVO enriched of essential oils, and packaging under modified atmosphere. In particular, $6 \mathrm{Kg}$ of raw meat was subdivided into 6 equal groups. To the 1st group, sausage samples without treatments (Cnt); in the 2 nd one, the samples dipped in sodium lactate solution (L). Thus, the meat pieces, prior to grinding, were dipped in pre-chilled $\left(4^{\circ} \mathrm{C}\right)$ solution of sodium salt of lactic acid ( $60 \% \mathrm{w} / \mathrm{w}$ syrup) (Giusto Faravelli Spa, Milan, Italy). After $10 \mathrm{~min}$ of dipping, meat pieces were allowed to drain for $5 \mathrm{~min}$ on sterile stainless wire mesh screen at ambient temperature $\left(18^{\circ} \mathrm{C}\right)$. In the $3^{\text {rd }}$ group, sample were treated with the EVO solution enriched of fennel and black pepper oil (FP) and in the $4^{\text {th }}$ one, sample treated with the EVO solution enriched of bay and nutmeg oil (BN). In particular, meat pieces, prior to grinding, were dipped into $100 \mathrm{~g}$ EVO solution enriched of best combinations of essential oils selected from the two CCD described in the previous trial and after dipping they were ground. In the last two groups, samples were obtained by combining the two tre atments. Thus, in the $5^{\text {th }}$ group, the raw meat was dipped into solution of sodium lactate and subsequently into EVO solution enriched of fennel and black pepper oil; in the $6^{\text {th }}$ batch, the meat was dipped into solution of sodium lactate and subsequently into EVO solution enriched of bay and nutmeg oil. The same series of operations that were performed previously were undertaken also in this trial and twenty sausages of $50 \mathrm{~g}$ for each group were obtained. The first 4 th groups were used as controls. All sausages were packaged under MAP $\left(30 \% \mathrm{CO}_{2} 70 \% \mathrm{~N}_{2}\right)$ and stored at $4^{\circ} \mathrm{C}$ for 20 days.

\section{Total Aerobic Bacteria (TAB)}

Twenty grams of sample were diluted in $180 \mathrm{ml}$ of peptone water and homogenized for $1 \mathrm{~min}$ in a blender (Stomacher, International PBI, Milan, Italy). Serial dilutions of sausage homogenates were plated in Plate Count Agar (Oxoid, Milan, Italy), incubated at $30^{\circ} \mathrm{C}$ for $48 \mathrm{~h}$.

In order to determine the microbiological acceptability limit (MAL; i.e., the storage time at which the viable cell concentration reaches its threshold value), the re-parameterized version of the Gompertz equation was fitted to the total aerobic bacterial data of the second trial (the threshold value was set to $107 \mathrm{cfu} / \mathrm{g}$ ), according to Mastromatteo et al. [46] and Del Nobile et al. [47].

\section{Sensory Analysis}

Seven experienced judges, staff of the Department of Agricultural Sciences, Food and Environment, evaluated the sausage samples. Sensory evaluation was based on an 8-point scale [48] to determine colour (8, no discoloration; 1, extreme discoloration) and odour (8, extremely desirable; 1 , extremely unacceptable/off-odours). On the basis of the above-mentioned attributes, panelist was also asked to score the overall quality of sausage using the same scale. Samples score equal or higher than 4 were considered acceptable. The same above-mentioned re-parameterized Gompertz equation was also used to fit the sensorial data of the second trial and allowed calculating the sensory acceptability limit (SAL), defined as the time at which the overall quality of the product reached the threshold (score $=4$ ) [47].

\section{Shelf life calculation}

The shelf life (SL) was calculated as the lowest value between MAL and SAL values of the second trial. In fact, it is the time at which one of the meat quality sub-indices reach the threshold acceptability [46]. 


\section{Statistical Analysis}

Differences between the calculated MAL, SAL and SL values were compared by one-way variance analysis (ANOVA). A Duncan's multiple range tests with the option of homogeneous groups $(\mathrm{P}<0.05)$, was used to determine significance between means. STATISTICA 7.1 for Windows (Stat-Soft, Inc, Tulsa, OK, USA) was used for this purpose.

The same statistical software was also used to fit a second-degree polynomial function to the independent variables using the following Eq. $\stackrel{(1)}{Y}=\sum(B i * x i)+\sum\left(B i i^{*} x i^{2}\right)+\sum(B i j * x i * x j)$

Where: $\mathrm{Y}$ is the dependent variable (log reduction value), $\mathrm{Bi}, \mathrm{Bii}$ and $\mathrm{Bij}$ are regression coefficients of the model, and $\mathrm{xi}$ and $\mathrm{xj}$ are the independent variables in coded values. Using this model, it was possible to determine the effects of linear, quadratic and interactive terms of the independent variables on the dependent one.

\section{Results and Discussion}

Microbial and sensory qualities were used to determine the shelf life of sausages. In particular, the study was divided into two sequential experimental trials. The first one was aimed to give an insight into the synergic effect of different essential oils to slow down microbial proliferation, and find the optimal essential oil concentration. The second trial was aimed to combine more preservative technologies to MAP. It is worth noting that sausage formulation was carried out in different periods along 1 year, thus different quality of meat was recorded. Therefore, to overcome this issue, the sausage shelf life values were compared with the related control sample prepared in the same experimental batch.

\section{Effects of active compounds on sausages quality}

Figure 1 illustrates the evolution of TAB viable cell concentration during the refrigerated storage for all runs obtained combining fennel and black pepper oil. This combination was chosen because fennel seeds and black peppercorns are usually used in the formulation of fresh sausages [49]. Aerobic plate counts often are chosen as an indicator of the effectiveness of hazard analysis critical control point (HACCP) plans, because data for all aerobic bacteria are more easily collected than data for pathogens of concern or other indicator organisms [50]. There was almost the same trend in all sausage samples; in fact a sharp increase occurred over the storage period. However, the cell load of most of the investigated runs was lower than those of the control (Cnt) along the entire storage period and there are significant differences. Recently there have been considerable studies involving essential oils and extracts of spices and herbs on inhibiting the growth of microbes [51], even though there are limited numbers of studies on food products [52-54]. During application of antimicrobial to foods, interactions between phenolic compounds and some food components can occur $[55,56]$ and their antimicrobial efficacy may be reduced by certain food components [57-59]. Ozcan et al. [14] found that fennel essential oils exhibit an inhibitory effect against a wide range of Bacillus species. Mimica-Dukic et al. [13] also reported that the essential oils of fennel are active against Aspergillus species. The essential oil of black peppercorn has been shown to possess antimicrobial activity $[16,60$ 62] also describes the antimicrobial activity of volatile oils of black pepper against Bacillus subtilis, Pseudomonas aeruginosa, Aspergillus niger, Candida albicans and Saccharomyces cerevisisae . Finally, Dorman and Deans [16] examined the antimicrobial activity of the volatile oils of black pepper, clove, geranium, nutmeg, oregano and thyme against 25 different genera of bacteria. All the bacterial strains tested showed some degree of sensitivity to volatile oils. The oil with the widest spectrum of antibacterial activity was found to be the one obtained from thyme, followed by oils from oregano, clove, nutmeg, black pepper and geranium.

To compare the antimicrobial effectiveness of different combinations against the TAB group, growth data were expressed as $\log$ reduction $(\Delta)$, calculated as follows [63]:

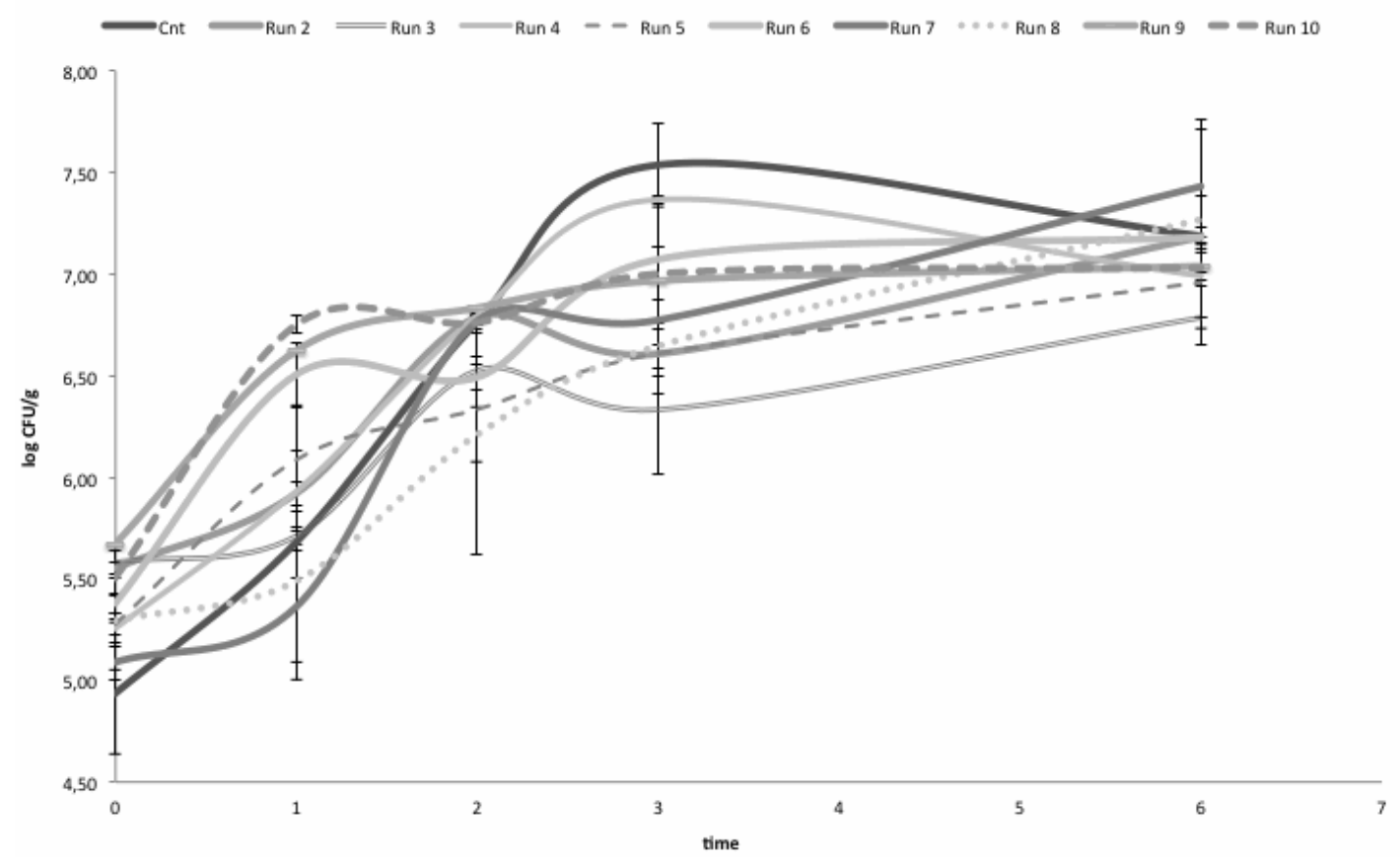

Figure 1: Evolution of TAB counts in fresh sausage during the storage period for all runs obtained combining fennel and black pepper oil. 


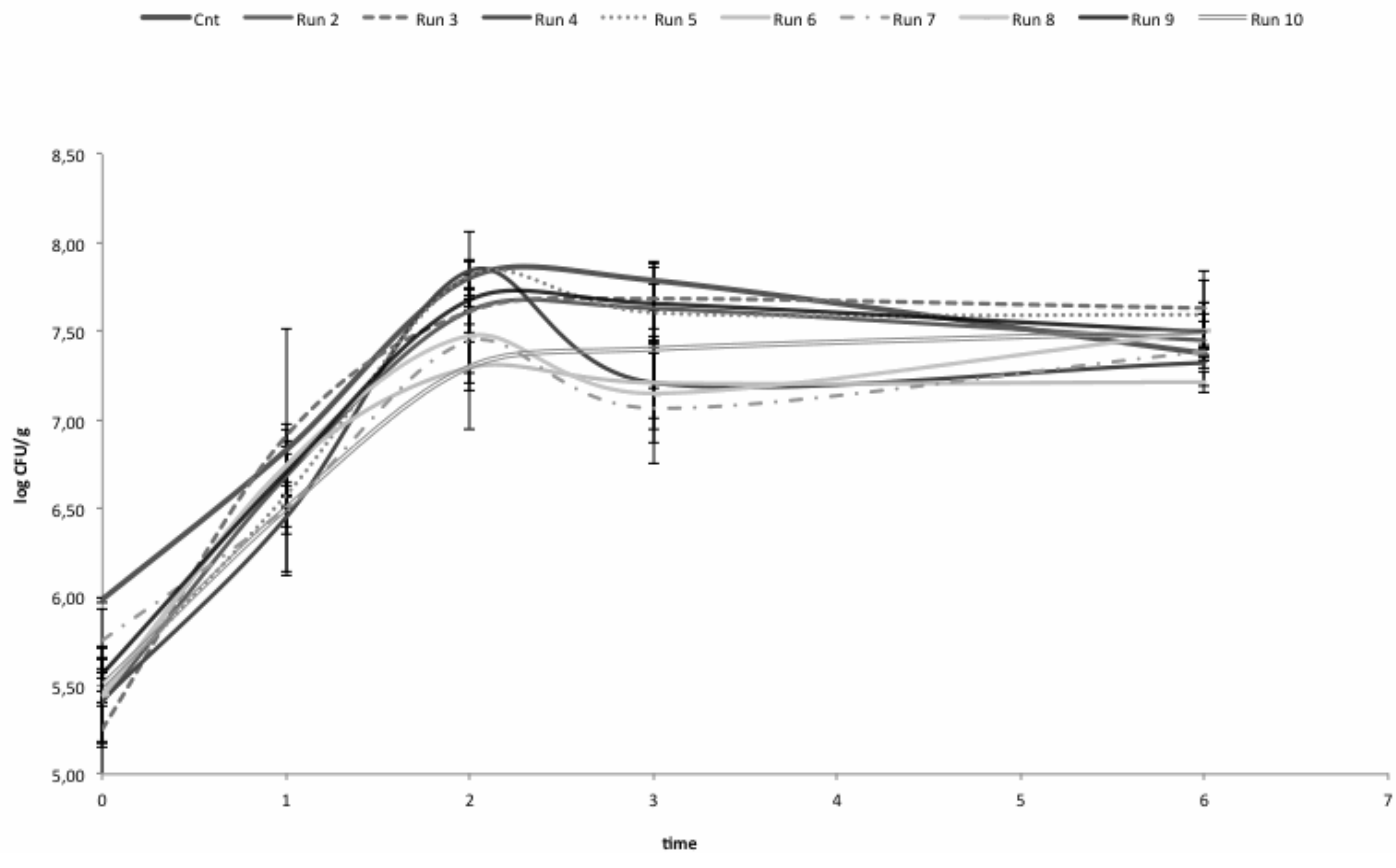

Figure 2: Evolution of $T A B$ counts in fresh sausage during the storage period for all runs obtained combining bay and nutmeg oil.

\section{$\Delta=\log$ CFUcg $-1-\log$ CFUag -1}

Where log CFUc is the cell load of TAB in Cnt sample (without oils) at time $t$ and log CFUa is the cell load of the samples treated with the oils at the same storage time.

The values of $\log$ reduction for different times of all monitoring runs were calculated. Some runs were found unsuitable to slow down the load of microorganisms investigated during the storage (data not shown). Overall, a log reduction $(\Delta)$ of TAB of about 1 log cycle was observed for the runs 1,2, 4 and 7 after 3 days of storage; this reduction has become smaller, in some cases it vanished, at the end of storage (6 days) in ordinary conditions.

In general, antimicrobial activity of essential oils depends on both their major constituents and their concentration [64]. The small amounts of minor components might also contribute the antimicrobial activity of the oils [65]. Moreover, their antimicrobial properties depend on genus, species and method of drying, extraction and geographical area (climatic factors) of spices [66]. To date, there are not researches that use the combination of fennel and black pepper oil to extend the shelf life of fresh sausage or in general meat products.

Figure 2 shows the evolution of $\mathrm{TAB}$ viable cell concentration during refrigerated storage of samples treated with the combinations of bay and nutmeg oils. This combination was chosen as an alternative to the previous one because the laurel and the nutmeg are sometimes used in the preparation of dishes made of pork meat. Data related to the control show the following trend: an increase in the viable cell concentration until the stationary phase is reached. As can be inferred from data shown in the figure, starting from the one day of storage, there was a strong increase in the cell loads of all samples, even though an antimicrobial effectiveness seems to be exerted in samples treated with essential oil. It is worth noting that in some cases the EO activity decreased considerably when added to a complex food system. For example, Firouzi et al. [67] found that oregano and nutmeg were effective against E. coli O157:H7 in a broth system, but had no effect in ready-to-cook chicken. The presence of high amount of protein and fat requires higher amount of either spices or their essential oils [68], and fat content might prevent penetration of these substances into the cells forming a coating layer on the surface of the cells [69]. In addition, antimicrobial activity against microorganisms involves different modes of action depending on major components of the oils. In general, the oils with high levels of eugenol (clove, bay and cinnamon leaf), cinnamamic aldehyde (cinnamon bark, cassia oil) and citral are usually strong antimicrobials $[70,71]$. The efficacy of runs on the growth of TAB was also determined (data not shown). In particular, run 3, 5, 6 and 7 caused a slight and steady log reduction during refrigerated storage; among these runs, the highest $\Delta$, about $0.7 \log$ cycle, was observed for the run 7 after 3 days of storage. In contrast, no inhibition was obtained in the case of run 1,2, 4 and 8 during the observed period of storage. Bay oil was found to be effective in the control of Listeria monocytogenes in ground chicken breast meat [72]. Similarly, Smith-Palmer et al. [73] determined the bactericidal effects of MIC (Minimum Inhibitory Concentration) values for L. monocytogenes and E. coli with bay oil of 0.04 and $0.1 \%(\mathrm{v} / \mathrm{v})$ respectively and they found the bay the most effective one against tested bacteria. Ameen [74] and Jaber [75] found that nutmeg oil had an antibacterial activity against Streptococcus pyogens, Staph. aureus, Pseudomonas aeruginosa and E. coli. To date, there are not studies that use the combination of bay and nutmeg oil to extend the shelf life of fresh sausage.

\begin{tabular}{|c|c|c|c|c|}
\hline $\begin{array}{l}\text { Dependent } \\
\text { variable }\end{array}$ & Best fit equations & $\mathbf{R}^{*}$ & $\mathrm{~F}^{\circ}$ & SE§ \\
\hline$\Delta \mathrm{t}=3$ & $\begin{array}{l}0.464859 \text { [fennel]-0.472859[black } \\
\text { pepper]-0.350598 [fennel] [black Pepper] }\end{array}$ & 0.97 & 38.97 & 0.21 \\
\hline$\Delta \mathrm{t}=3$ & 0.207 [bay] & 0.79 & 15.27 & 0.26 \\
\hline \multicolumn{5}{|c|}{$\begin{array}{l}\text { * Regression coefficient } \\
\text { - Fisher test value } \\
\text { § Standard error } \\
\text { Table 2: Best fit equations describing the main interactive and quadratic effect of } \\
\text { essential oils on log reduction }(\Delta) \text { values. }\end{array}$} \\
\hline
\end{tabular}



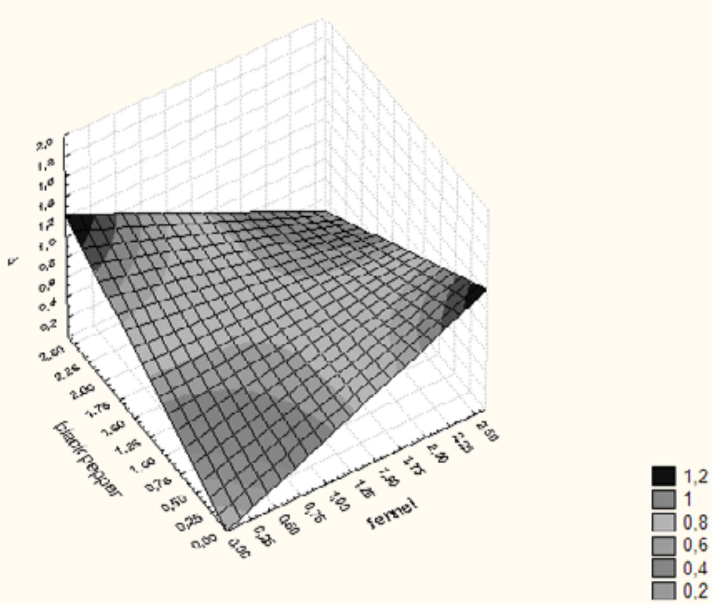

Figure 3: Effects of the interaction [fennel] [black pepper] on log reduction value $(\Delta)$.

\begin{tabular}{|c|c|c|c|}
\hline & MAL & SAL & SL \\
\hline Cnt-MA & $1.91 \pm 0.53^{\mathrm{b}}$ & $>3$ & $1.91 \pm 0.53^{\mathrm{b}}$ \\
\hline L-MA & $>17$ & $15.07 \pm 0.48$ & $15.07 \pm 0.48^{\mathrm{d}}$ \\
\hline FP-MA & $5.31 \pm 1.21^{\mathrm{a}}$ & $>7$ & $5.31 \pm 1.21^{\mathrm{a}}$ \\
\hline BN-MA & $4.99 \pm 0.66^{\mathrm{a}}$ & $>6$ & $4.99 \pm 0.66^{\mathrm{a}}$ \\
\hline L-FP-MA & $13.75 \pm 0.69^{\mathrm{c}}$ & $>15$ & $13.75 \pm 0.69^{\mathrm{c}}$ \\
\hline L-BN-MA $^{\mathrm{c}}$ & $18.32 \pm 0.58^{\mathrm{d}}$ & $>20$ & $18.32 \pm 0.58^{\mathrm{e}}$ \\
\hline
\end{tabular}

Data in column with different letters are significantly different $(P<0.05)$. Values are means \pm Standard error for $n=2$.

Table 3: Shelf life (SL) of sausage samples evaluated as the lowest value between the microbial acceptability limit (MAL) and the sensorial acceptability limit (SAL).

Surface methodology was employed to investigate the synergic effect of the selected natural compounds on the quality decay of fresh sausage. The obtained polynomial functions describing these effects are reported in Table 2. The $\mathrm{R}$ values indicate the adequacy of the models proposed; the $\mathrm{F}$ values indicate a high level of significance $(\mathrm{P}<$ 0.0001). A three-dimensional surface plot can be advantageously used to assess the influence of the independent variables on $\Delta$ values. In particular, 3-D graphs can be obtained by plotting the $\Delta$ values against two investigated independent variables (fennel and black pepper oils) (Figure 3). As can be inferred from the figure, a maximum is present when the two essential oils are used individually at the highest concentration or when one of them is at high and the other are used at low concentrations. In contrast, an antagonistic effect was found when the essential oils were used all at the lowest concentration. Therefore, combination of oils may lead to additive, synergistic or antagonistic effects, as stated by Delaquis et al. [76] and Fu et al. [77]. The figure 4 shows the 3-D graph for $\Delta$ values of the combination of bay and nutmeg oils. It is interesting to note that a marked log reduction is present when the bay oil is at high concentration and any concentration of nutmeg oil. Unfortunately, a comparison between the selected antimicrobial compounds with published data is very difficult, as the outcome of a test is affected by numerous factors, such as the food matrix and, of course, the source of antimicrobial compounds used [78].

The TAB cell load of the two CCD was experimentally analyzed and the results were statistically compared with the predicted values of the mathematical model. In addition, it has been possible to identify the optimal concentration to be used for the subsequent trial using the error calculation. In particular, the best combinations are the run 7 made up of $1.25 \%$ fennel and $2.5 \%$ black pepper and the run 5 made up of $2.5 \%$ bay and $1.25 \%$ nutmeg.

\section{Effects of combined treatments on sausages quality}

The above-mentioned data suggest that the dipping of meat surface with essential oils cannot assure the quality of fresh sausage for long time. Therefore, in this experimental trial, the dipping with EO has been combined with dipping in sodium lactate solution and packaging under MAP. In the Table 3, the MAL values of investigated samples are listed. As can be seen, the Cnt-MA went beyond the threshold after about 2 days of storage. About 5 days were found for samples treated with the optimum concentration of essential oils and packaged under MAP. Chouliara et al. [52] also found that MAP (70\% CO 30\% $\left.\mathrm{N}_{2}\right)$ and oregano oil had inhibitory effects on total viable count in fresh chicken meats. On the other hand, the MAL values of sample treated with sodium lactate and packaged under MAP exceeded the monitored storage period (i.e., 17 days). The bacteriostatic property of sodium lactate may result from intracellular acidification $[79,80]$. Finally, the MAL value of LFP-MA and LBN-MA samples were 13.7 and 18.3 days, respectively. Data suggest that MAP combined with the dipping treatments enhanced microbial stability by inhibiting the proliferation of TAB.

The SAL values are listed in the second column of Table 3. The sensory quality of sausage steadily decreased, regardless of the strategies adopted. As can be inferred, most of the samples are acceptable for the entire sampling period; in contrast, the sample L-MA shows a SAL of about 15. It is interesting to note that the use of essential oils improved the sensory quality of sausage; therefore, a careful selection of them is required. In fact Mastromatteo et al. [46] found that lemon and thymol recorded the highest sensory score combining different MAPs with natural essential oils on shelf life of reduced pork back fat content sausages.

Data on shelf life of investigated sausages are also reported in the third column of the Table 3. As can be inferred from these data, the microbial quality is responsible for the unacceptability of the all samples, except for L-MA sample. However, the combination of dip
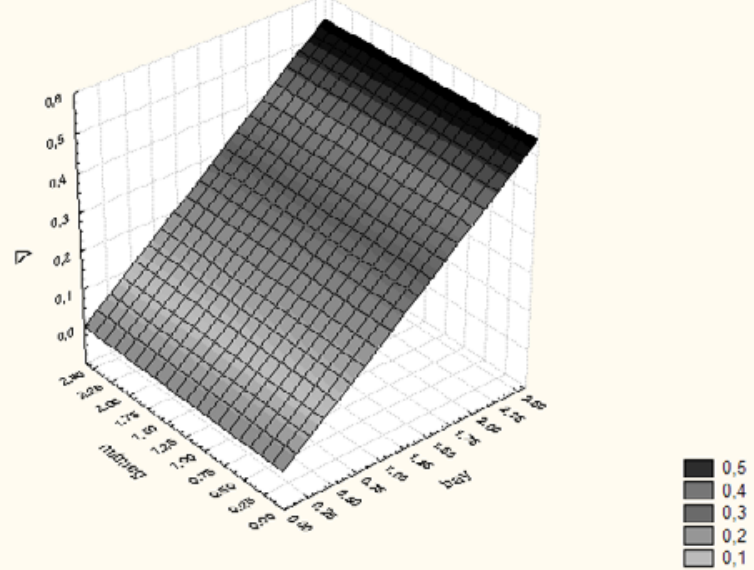

Figure 4: Effects of the interaction [bay] [nutmeg] on log reduction value $(\Delta)$. 
in $60 \%$ sodium lactate, in the essential oils and the packaging under MAP are the most effective treatment in retaining good microbial characteristics. On the contrary, the sensory quality does not limit the shelf life of the investigated food products. In particular, the treatment with antimicrobial compounds improved texture and discoloration of sausages and inhibited off odour formation. In addition to its desirable effect on sensory attributes, sodium lactate has an antimicrobial effect.

\section{Conclusion}

These results are in agreement with those of Incoronato et al. [28] who studied the effect of meat dipping prior to grinding in combination with MAP on burgers. They are also in agreement with those reported by Gammariello et al. [27], who reported an increase of ready-to-cook meal shelf life combining dipping of meat in sodium lactate solution and packaging under MAP. Finally, hurdle technology which involves simultaneous multiple preservation approaches has generally met with success in controlling pathogens and maintaining food quality during storage [81]. For the sake of clarity, the percentage shelf life increase of each tested sample was also calculated in comparison with the CntMAP sample; values of $620 \%$ and $859 \%$ were estimated for LFP-MA and LBN-MA samples, respectively.

\section{References}

1. Chung KT, Dickson JS, Crouse JD (1989) Effects of nisin on growth of bacteria attached to meat. Appl Environ Microbiol 55: 1329-1333.

2. Cutter CN, Siragusa GR (1996) Reductions of Listeria innocua and Brochothrix thermosphacta on beef following nisin spray treatments and vacuum packaging. Food Microbiol 13: 23-33.

3. Cutter CN (1999) The effectiveness of triclosan-incorporated plastic against bacteria on beef surfaces. J Food Prot 62: 474-479.

4. Cutter CN (2000) Antimicrobial effect of herb extracts against Escherichia col O157:H7, Listeria monocytogenes and Salmonella typhimurium associated with beef. J Food Prot 63: 601-607.

5. Gill AO, Holley RA (2000) Surface application of lysozyme, nisin, and EDTA to inhibit spoilage and pathogenic bacteria on ham and bologna. J Food Prot 63: $1338-1346$

6. Nattress FM, Yost CK, Baker LP (2001) Evaluation of the ability of lysozyme and nisin to control meat spoilage bacteria. J Food Microbiol 70: 111-119.

7. Shetty K, Lin YT (2005) Phenolic antimicrobials from plants for control of bacterial pathogens. Food Biotechnology., CRC Press, Boca Raton.

8. Lin YT, Labbe RG, Shetty K (2004) Inhibition of Listeria monocytogenes in fish and meat systems using oregano and cranberry synergies. Appl Environ Microbiol 70: 5672-5678

9. Burt SA, Reinders RD (2003) Antimicrobial activity selected plant essential oils against Escherichia coli O157:H7. Lett Appl Microbiol 36: 162-167.

10. Irkin R, Korukluoglu M (2009a) Effectiveness of Cymbo- pogon citratus L.essential oil to inhibit the growth of some fila- mentous fungi and yeasts. J Med Food 12: 193-197.

11. Irkin R, Korukluoglu M (2009b) Growth inhibition of pathogenic bacteria and some yeasts by selected essential oils and survival of Listeria monocytogenes and Candida albicans in apple carrot juice. Foodborne Pathg Dis 6: 387-394.

12. Oktay M, Gulcin I, Kufrevioglu OI (2003) Determination of in vitro antioxidan activity of fennel (Foeniculum vulgare) seed extracts. Lebensm Wiss Technol 36: $263-271$.

13. Mimica-Dukic N, Kujundzic S, Sokovic M, Couladis M (2003) Essential oil composition and antifungal activity of Foeniculum vulgare Mill obtained by different distillation conditions. Phytother Res 17: 368-371.

14. Ozcan MM, Chalchat JC, Arslan D, Ates A, Unver A (2006) Comparative essential oil composition and antifungal effect of bitter Fennel (Foeniculum vulgare ssp. piperitum) fruit oils obtained during different vegetation. J Med Food 9: 552-561.

15. Mata AT, Proenca C, Ferreira AR, Serralheiro MLM, Nogueira JMF, et al.
(2007) Antioxidant and antiacetylcholinesterase activities of five plants used as Portuguese food species. Food Chem 103: 778-786.

16. Dorman HJD, Deans SG (2000) Antimicrobial agents from plants: antibacterial activity of plant volatile oils. J Appl Microbiol 88: 308-316

17. Skerget M, Kotnik P, Hadolin M, Hras AR, Simonie M, et al. (2005) Phenols proanthocyanidins, flavones and flavonols in some plant materials and their antioxidant activities. Food Chem 89: 191-198.

18. Yalçın H, Akın M, Şanda M, Çakır A (2007) Gas Chromatography/Mass Spectrometry Analysis of Laurus nobilis Essential Oil Composition of Northern Cyprus. J Medicinal Food 10: 715-719.

19. Simic M, Kundakovic N, Kovacevic N (2003) Preliminary Assay on the Antioxidative Activity of Laurus nobilis Extracts. Fitoterapia74: 613- 616.

20. Ferreira A, Proenç C, Serralheiro MLM, Araujo MEM (2006) The in Vitro Screening for Acetylcholinesterase Inhibition and Antioxidant Activity of Medicinal Plants from Portugal. J Ethnopharmacology 108: 31-37.

21. Dorman HJ, Deans SG, Noble RC, Surai P (1995) Evaluation in vitro of plant essential oils as natural antioxidants. J Essential Oil Res 7: 645-651.

22. Murcia MA, Egea I, Romojaro F, Parras P, Jimenez AM, et al. (2004) Antioxidant evaluation in dessert spices compared with common food additives. Influence of irradiation procedure. J Agric Food Chem 52: 1872-1881.

23. Parle M, Dhingra D, Kulkarni SK (2004) Improvement of mouse memory by Myristica fragrans seeds. J Med Food 7: 157-161.

24. Lucera A, Costa C, Conte A, Del Nobile MA (2012) Food applications of natural antimicrobial compounds. Front Microbiol 3: 287.

25. Maca JV, Miller RK, Acuff GR (1997) Microbiological, sensory and chemical characteristics of vacuum-packaged ground beef patties treated with salts of organic acids. J Food Sci 62: 591-596.

26. Sallam KI, Samejima K (2004) Microbiological and chemical quality of ground beef treated with sodium lactate and sodium chloride during refrigerated storage. LWT 37: 865-871.

27. Gammariello D, Incoronato AL, Conte A, Del Nobile MA (2014) Use of sodium lactate and modified atmosphere packaging for extending the shelf life of Ready-to-Cook fresh meal.

28. Incoronato AL, Gammariello D, Conte A, Del Nobile MA (2014) Technological solutions to increase shelf life of fresh meat burgers. J Food Process Preserv.

29. Williams SK, Phillips K (1998) Sodium lactate affects sensory and objective characteristics of tray-packed broiler chicken breast meat. Poultry Sci 77: 765769

30. Boskou G, Debevere J (2000) Shelf life extension of cod fillets with an acetate buffer spray prior to packaging under modified atmosphere. Food Add Contam 17: $17-25$.

31. Zhuang RY, Huang YW, Beuchat LR (1996) Quality changes during refrigerated storage of packaged shrimp and catfish fillets treated with sodium acetate sodium lactate, or propyl gallate. J Food Sci 61: 241-244.

32. Sallam KI (2007) Antimicrobial and antioxidant effects of sodium acetate sodium lactate, and sodium citrate in refrigerated sliced salmon. Food Contro 18: $566-575$.

33. McWilliam Leitch EC, Stewart CS (2002) Susceptibility of Escherichia coli 0157 and non-O157 isolates to lactate. Lett Appl Microbiol 35: 176-180.

34. Serdengecti N, Yildirimi I, Gokoglu N (2006) Effects of sodium lactate, sodium acetate and sodium diacetate on microbiological quality of vacuum-packed beef during refrigerated storage. J Food Safety 26: 62-71.

35. Shelef LA (1994) Antimicrobial effects of lactates: A review. J Food Prot 57 $445-450$.

36. Wang M, Kikuzaki H, Zhu N, Sang S, Nakatani N, et al. (2000) Isolation and structural elucidation of two new glycosides from sage (Salvia officinalis L). J Agric Food Chem 48: 235-238.

37. Papadopoulos LS, Miller RK, Ringer LJ, Cross HR (1991) Sodium lactate effect on sensory characteristics, cooked meat colour and chemical composition. J Food Sci 56: 621-635.

38. Kuo JC, Diesel J, Leistner L (1994) Effects of sodium lactate and storage temperature on growth and survival of Salmonella in Chinese sausage. Food Sci. 21: 182-196. 
Citation: Gammariello D, Incoronato AL, Conte A, DelNobile NA (2015) Use of Antimicrobial Treatments and Modified Atmosphere to Extend the Shelf Life of Fresh Sausages. J Food Process Technol 6: 456. doi:10.4172/2157-7110.1000456

Page 7 of 7

39. Silliker JA, Wolfe SK (1980) Microbiological safety considerations in controlledatmosphere storage of meats. Food Technol 34: 59-63.

40. Farber JM (1991) Microbiological aspects of MAP technology, A review. J Food Prot 94: 58-70.

41. Chouliara, E, Kontominas MG (2006) Combined effect of thyme essential oil and modified atmosphere packaging to extend shelf life of fresh chicken meat. Studium Press, USA.

42. Narasimha DR, Sachindra NM (2002) Modified atmosphere and vacuum packaging of meat and poultry products. Food Rev Int 18: 263-293.

43. Goulas AE (2008) Combined effect of chill storage and modified atmosphere packaging on mussels (Mytilus galloprovincialis) preservation. Packag Technol Sci 21: 247-255

44. Lemay MJ, Choquette J, Delaquis PJ, Gariepy C, Rodrigue N, et al. (2002) Antimicrobial effect of natural preservatives in a cooked and acidified chicken meat model. Int J Food Microbiol 78: 217-226.

45. Box GEP, Hunter WG, Hunter JS (1978) Statistics for Experimenters. An Introduction to Design Data Analysis and Model Building, John Wiley \& Sons, New York.

46. Mastromatteo M, Incoronato AL, Conte A, Del Nobile MA (2011) Shelf life of reduced pork back-fat content sausages as affected by antimicrobial compounds and modified atmosphere packaging. Int J Food Microbiol 150: 1-7.

47. Del Nobile MA, Conte A, Cannarsi M, Sinigaglia M (2009) Strategies for prolonging the shelf life of minced beef patties. J Food Safety 29: 14-25.

48. Das AK, Anjaneyulu ASR, Verma AK, Kondaiah N (2008) Effect of full-fat soy paste and soy granules on quality of goat meat patties. Int J Food Sci and Technol 43: 383-392.

49. Normanno G, Parisi A, Dambrosio A, Quaglia NC, Montagna CO, et al (2004) Typing of Escherichia coli O157:H7 isolated from fresh sausage. Food Microbiol 21: 79-82.

50. Chong-Hae H, Ewen T, Gyung-Jin B (2008) Aerobic plate counts as a measure of hazard analysis critical control point effectiveness in a pork processing plant. J Food Protect 71: 1248-1252.

51. Falzari LM, Menary RC (2003) Chamomile for oil and Dried flowers. Australia.

52. Chouliara E, Karatapanis A, Savvaidis IN, Kontominas MG (2007) Combined effect of oregano essential oil and modi- fied atmosphere packaging on shelflife extension of fresh chick- en breast meat, stored at $4^{\circ} \mathrm{C}$. Food Microbiol 24 : 607-617.

53. Corbo MR, Speranza B, Filippone A, Granatiero S, Conte A, et al. (2008) Study on the synergic effect of natural compounds on the microbial quality decay of packed fish hamburger. Int J Food Microbiol 127: 261-267.

54. Nedorostova L, Kloucek P, Kokoska L, Stolcova M, Pulkrabek J (2009) Antimicrobial properties of selected essential oils in vapour phase against foodborne bacteria. Food Cont 20: 157-160.

55. Ultee A, Gorris LGM, Smid EJ (1998) Bactericidal activity of carvacrol towards the food borne pathogen Bacillus cereus. J Appl Microbiol 89: 2111-2218.

56. Nychas GJE, Tassou CC (2000) Traditional preservatives-oils and spices Academic Press, San Diego.

57. Glass KA, Johnson EA (2004) Antagonistic effect of fat on the antibotulinal activity of food preservatives and fatty acids. Food Microbiol 21: 675-682.

58. Raybaudi-Massillia RM, Mosqueda-Melgar J, Soliva-Fortuny R, Martin-Belloso $O$ (2009) Control of pathogenic and spoilage microorganisms in fresh cut fruits and fruit juices by traditional and alternative natural antimicrobials. Compr Rev Food Sci Food Safety 8: 157-180.

59. Gutierrez J, Barry-Ryan C, Bourke P (2008) The antimicro- bial efficacy of plant essential oil combinations and interactions with food ingredients. Int $\mathrm{J}$ Food Microbiol 124: 91-97.

60. Larhsini M, Oumoulid L, Larze HB, Bousaid M, Bekkouche K, et al. (2001) Antimicrobial activity of some Moroccan Medicinal Plants. Phytother Res 15: 250-252.

61. Sasidharan S, Nilawatyi R, Xavier R, Latha LY, Amala R (2010) Wound healing potential of Elaeis guineensis Jacq leaves in an affected albino rat model. Molecules 15: 3186-3199.

62. Shiva Rani SK (2013) Antimicrobial Activity of Black Pepper (Piper nigrum L.).
Global J Pharmacology 7: 87-90.

63. Mastromatteo M, Lucera A, Sinigaglia M, Corbo MR (2009) Combined effects of thymol, carvacrol and temperature on the quality of non-conventional poultry patties. Meat Sci 83: 246-254.

64. Farag R, Daw Z, Hewedi F, El-Baroty G (1989) Antibacterial Activity of some Egyptian Spices and Essential Oils. J Food Protect 52: 665-667.

65. Ouattara B, Simard RE, Holley RA, Piette GJP, Begin A (1997) Antibacteria activity of selected fatty acids and essential oils against six meat spoilage organisms. Int J Food Microb 37: 155-162.

66. Jerkovic I, Mastelic J, Milos M (2001) The impact of both the season of collection and drying on the volatile constituents of Origanum vulgare $L$. spp. Hirtum grown wild in Croatia. Int J Food Sci Technol 36: 649-654.

67. Firouzi R, Shekarforoush SS, Nazer AH, Borumand Z, Jooyandeh AR (2007) Effects of essential oils of oregano and nutmeg on growth and survival of Yersinia enterocolitica and Listeria monocytogenes in barbecued chicken. $J$ Food Protect 70: 2626-2630.

68. Shelef LA, Jyothi EK, Bulgarelli MA (1984) Growth of enteropathogenic and spoilage bacteria in sage-containing broth and foods. J Food Sci 49: 737-740.

69. Farbood MI, Macneil JH, Ostovar K (1976) Effects of rosemary spice extractive on growth of microorganisms in meats. J Milk Food Technol 39: 675-679.

70. Lis-Balchin M, Deans SG, Eaglesham E (1998) Relationship between bioactivity and chemical composition of commercial essential oils. Flav Frag J 13: 98-104

71. Davidson PM, Naidu AS (2000) Phytophenols. CRC Press Boca Raton, Florida

72. Irkin R, Esmer OK (2010) Control of Listeria monocytogenes in ground chicken breast meat under aerobic, vacuum and modified atmosphere packaging conditions with or without the presence of bay essential oil at $4^{\circ} \mathrm{C}$. Food Sci Technol Res 16: 285-290.

73. Smith-Palmer A, Stewart J, Fyfe L (1998) Antimicrobial properties of plant essential oils and essences against five important food-borne pathogens. Lett Appl Microbiol 26: 118-122.

74. Ameen Sabah J (2011) Antimicrobial activity of nutmeg extracts against Staphylococcus aureus and Escherichia Coli. Iraqi Academic Scientific Journals 25:159-163.

75. Jaber NN (2005) Study of the antimicrobial activity of the oils isolated from some plants. College of Education, University of Basra, Iraq.

76. Delaquis PJ, Stanich K, Girard B, Mazza G (2002) Antimicrobial activity of individual and mixed fractions of dill, cilantro, coriander and eucalyptus essential oils. Int J Food Microbiol 74: 101-109.

77. Fu YJ, Zu YG, Chen LY, Shi XG, Wang Z, et al. (2007) Antimicrobial activity of clove and rosemary essential oils alone and in combination. Phytotherapy Research 21: 989-994

78. Rios JL, Recio MC, Villar A (1988) Screening methods for natural products with antibacterial activity: a review of the literature. J Ethnopharmacol 23: 127-149.

79. Bradford DD, Huffman DL, Egbert WR, Jones WR (1993) Low-fat fresh pork sausage patty stability in refrigerated storage with potassium lactate. $\mathrm{J}$ Food Sci 58: 488-491.

80. Eklund T (1980) Inhibition of growth and uptake processes in bacteria by some chemical food preservation. J Bacteriol 48: 423-432.

81. Leistner $L$ (2000) Basic aspects of food preservation by hurdle technology. Int J Food Microbiol 55: 181-186. 